\title{
CORRECTION
}

\section{Correction to: Late Oligocene-Early Miocene shortening in the Thrace Basin, northern Aegean}

\author{
Ümitcan Erbil ${ }^{1,4}$ (D) Aral I. Okay ${ }^{1,2}$ (1) Aynur Hakyemez ${ }^{3}$ (1)
}

Published online: 7 July 2021

(c) Geologische Vereinigung e.V. (GV) 2021

\section{Correction to: International Journal of Earth Sciences https://doi.org/10.1007/s00531-021-02047-3}

In the online published article, the article title was published incorrectly. The correct title is given below.

Late Oligocene-Early Miocene shortening in the Thrace Basin, northern Aegean

The original article can be found online at https://doi.org/10.1007/ s00531-021-02047-3.

Ümitcan Erbil

erbilumt@gmail.com; umit.erbil@fu-berlin.de

Aral I. Okay

okay@itu.edu.tr

Aynur Hakyemez

aynurhakyemez@yahoo.com

1 Eurasia Institute of Earth Sciences, Istanbul Technical University, 34469 Maslak, Turkey

2 Department of Geology, Faculty of Mines, Istanbul Technical University, 34469 Maslak, Turkey

3 Department of Geological Research, General Directorate of Mineral Research and Exploration (MTA), 06800 Ankara, Turkey

4 Present Address: Institut für Geologische Wissenschaften, Freie Universität Berlin, Malteserstrasse 74-100, 12249 Berlin, Germany 